Revta brasil. Bot., São Paulo, V.24, n.3, p.289-294, set. 2001

\title{
Comparative analysis of leaf cell-wall polysaccharides of Dialypetalanthus fuscescens and Bathysa meridionalis: evidence of biochemical similarities between Dialypetalanthaceae and Rubiaceae-Cinchonoideae
}

\author{
FABIO MORAES ${ }^{1}$, MICHAEL G. HAHN ${ }^{2}$ and MARCIA R. BRAGA ${ }^{1,3}$
}

(received: January 5, 2001; accepted: June 6, 2001)

\begin{abstract}
Comparative analysis of leaf cell-wall polysaccharides of Dialypetalanthus fuscescens and Bathysa meridionalis: evidence of biochemical similarities between Dialypetalanthaceae and Rubiaceae-Cinchonoideae). Dialypetalanthus fuscescens is an Amazonian endemic species with problematic taxonomic position. This neotropical rainforest tree belongs to the monospecific Dialypetalanthaceae. In the present work, we analysed the leaf cell-wall polysaccharide composition of Dialypetalanthus fuscescens and compared it to that of Bathysa meridionalis (Rubiaceae-Cinchonoideae). Glycosyl composition and glycosyl-linkage analysis indicated that both species have similar cell wall composition. Arabinogalactans were the major component of the pectic polysaccharides and xylans, although being reported in minor amounts in dicots, were found to be the predominant hemicellulosic polysaccharide in cell walls of both species. These findings are in agreement with previous data on cell wall composition reported for Rubiaceae and corroborate the current suggestion of the possible link between this family and Dialypetalanthaceae.
\end{abstract}

RESUMO - (Análise comparativa de polissacarídeos de paredes celulares de folhas de Dialypetalanthus fuscescens e Bathysa meridionalis: evidências de similaridades bioquímicas entre Dialypetalanthaceae e Rubiaceae-Cinchonoideae). Dialypetalanthus fuscescens é uma espécie endêmica da Amazônia com posição taxonômica incerta. Esta espécie da floresta úmida neotropical pertence à família monoespecífica Dialypetalanthaceae. Neste trabalho, foi analisada a composição dos polissacarídeos de paredes celulares de folhas de Dialypetalanthus fuscescens e esta comparada com Bathysa meridionalis (RubiaceaeCinchonoideae). Análises de composição química e ligações glicosídicas demonstraram que ambas as espécies possuem composição química da parede celular bastante similar. Arabinogalactanos foram identificados como os polissacarídeos pécticos predominantes e os xilanos, embora menos freqüentes em dicotiledôneas, foram encontrados em grandes quantidades na fração hemicelulósica de ambas as espécies. Esses resultados estão de acordo com outros previamente reportados para Rubiaceae e constituem uma evidência adicional da possível proximidade taxonômica de Dialypetalanthaceae com Rubiaceae, como atualmente aceito.

Key words - Dialypetalanthaceae, Amazonian tree, Bathysa meridionalis, Rubiaceae, Cinchonoideae, cell-wall polysaccharides

\section{Introduction}

Dialypetalanthus fuscescens Kuhlm. is an endemic Amazonian tree, being the only species of the Dialypetalanthaceae. Its taxonomic position is problematic since this species combines characters such as buds protected by stipules, paracytic stomata, numerous unitegmic ovules, and a well-developed endosperm that suggest a close relationship with the Rubiaceae, with primitive features such as free petals and dimerous floral whorls that are enough to set it apart from the Gentianales (Piesschaert et al. 1997). When in vegetative stage, $D$. fuscescens is hardly

1. Instituto de Botânica, Seção de Fisiologia e Bioquímica de Plantas, Caixa Postal 4005, 01061-970 São Paulo, SP, Brasil.

2. University of Georgia, Complex Carbohydrate Research Center and Department of Botany, 220 Riverbend Road, 30602-4712 Athens, GA, USA.

3. Corresponding author: bragamr@canalvip.com.br distinguishable from certain RubiaceaeCinchonoideae (Piesschaert et al. 1995).

In the past, $D$. fuscescens was suggested to be closely related to the Myrtales or Rosales (Rizzini \& Occhioni 1949, Cronquist 1968). More recently the affinity of this species with Rubiales or Gentianales has been proposed (Dahlgren \& Thorne 1984) and accepted instead. However, the lack of ontogenetic and micro- and macromolecular data on D. fuscescens has limited a proper judgement about the possible relationships of this species with other plants (Piesschaert et al. 1997).

Cell wall composition has been used as a taxonomic character to distinguish plant taxa at several hierarchic levels (Reid \& Meier 1970, Buckeridge et al. 1995, Carpita 1996, Braga \& Dietrich 1999, Szweykowski \& Buczkowska 1999). Variations in composition and fine structure of cellwall polysaccharides have been shown to be useful, in some cases, to substantiate plant phylogenetic relationships proposed on the basis of anatomical 
features and chemical constituents (Buckeridge et al. 1995, Carpita 1996, Carnachan \& Harris 2000).

In the present work, we analysed the polysaccharide composition of leaf cell walls of $D$. fuscescens and compared it to that of Bathysa meridionalis, a Rubiaceae-Cinchonoideae species.

\section{Material and methods}

Plant material - Leaves of Dialypetalanthus fuscescens Kuhlm. (Dialypetalanthaceae) were collected in the Amazonian forest (Buriti, Rondônia, Brazil) and of Bathysa meridionalis Smith \& Downs (Rubiaceae-Cinchonoideae) in the forest of Reserva Biológica do Parque Estadual das Fontes do Ipiranga (São Paulo, SP, Brazil). Voucher samples are filed in the Herbarium "Eneida K. Fidalgo" (Instituto de Botânica, SP, Brazil) with numbers SP 300077 and SP 28634, respectively.

Preparation of cell walls - Cell walls were prepared as alcoholinsoluble residue (AIR) as described by Fry (1988). The AIR was washed in acetone (x5) dried at room temperature, and subjected to sequential extraction. Prior to extraction, fibers were separated using a Granutest sieve (20 mesh) and discarded. Fractionation of cell-wall material - Cell walls were delignified with $3 \%$ sodium chlorite $\left(\mathrm{NaClO}_{2}\right)$ in $0.4 \%$ acetic acid at $80{ }^{\circ} \mathrm{C}$. After $1 \mathrm{~h}, \mathrm{NaClO}_{2}$ and acetic acid concentration were increased to $4 \%$ and $0.8 \%$, respectively, and the incubation was carried out for an additional $2 \mathrm{~h}$ with continuous shaking. The insoluble material was suspended in deionized water and centrifuged at $2500 \mathrm{~g}$. The pellet was washed twice in water, recovered by centrifugation and freeze-dried. The supernatants were combined, dialyzed for $48 \mathrm{~h}$, lyophilized, weighed and considered as $\mathrm{NaClO}_{2}$ fraction. Cell-wall polysaccharides were obtained from the delignified pellet as described by Gorshkova et al. (1996). The pellet was initially extracted twice with $0.5 \%$ ammonium oxalate $(\mathrm{pH} 7)$ at $80{ }^{\circ} \mathrm{C}$ under $\mathrm{N}_{2}$ for $1 \mathrm{~h}$ each. The depectinized cell walls were then extracted twice with $4 \mathrm{M} \mathrm{KOH}$ (containing $3 \mathrm{mg} / \mathrm{ml}$ sodium borohydride) at $25{ }^{\circ} \mathrm{C}$ under $\mathrm{N}_{2}$ for $1 \mathrm{~h}$ each. The fraction yields were determined gravimetrically.

Gel-permeation chromatography - Fractions dissolved in $150 \mathrm{mM}$ Mcllvaine buffer ( $\mathrm{pH}$ 5.2) were loaded onto a Sepharose 4B column $(1.5 \mathrm{~cm}$ i.d. x $87 \mathrm{~cm}$, Pharmacia). Eluted fractions $(3 \mathrm{ml})$ were collected and assayed for uronic acids and sugar content. Linear dextrans (Mr 2,000 and $76 \mathrm{kDa}$ ) were used for calibration.

Colorimetric assay - Uronic acid content was determined by the m-hydroxybiphenyl method (Filisetti-Cozzi \& Carpita 1991) using galacturonic acid as standard. Sugar content was estimated by phenol-sulfuric assay using glucose as standard (Dubois et al. 1956).

Sugar composition - Neutral and acidic glycosyl compositions were determined as described (York et al. 1985). Briefly, samples were hydrolyzed with $1.0 \mathrm{M}$ methanolic- $\mathrm{HCl}$ for $16 \mathrm{~h}$ at $80^{\circ} \mathrm{C}$. The released methylglycosides were dried down and $\mathrm{N}$-acetylated using methanol and acetic anhydride (1:1, $\mathrm{v}: \mathrm{v})$ for $15 \mathrm{~min}$ at $45{ }^{\circ} \mathrm{C}$. The acetylated samples were trimethyl-silylated (TMS) with Tri-Sil and resolved on a $30 \mathrm{~m}$ DB- 1 column $(0.25 \times 0.25$, i.d.; J \& W Scientific, Folsom, CA) in a Hewlett Packard 5985 GC-MS system using myoinositol as internal standard. The following temperature conditions were used: $160^{\circ} \mathrm{C}$ for $3 \mathrm{~min}$, then raised to $200^{\circ} \mathrm{C}$ at $2{ }^{\circ} \mathrm{C} / \mathrm{min}$, and increased to $260^{\circ} \mathrm{C}$ at $10^{\circ} \mathrm{C} / \mathrm{min}$. A standard of derivatized methylglycosides were also run for comparison and identification of peaks.

Sugar linkage analysis - Glycosyl linkage composition was analysed by Gas Chromatography coupled to mass spectrometry (GC-MS) of partially O-methylated alditol acetates. Per- $O$-methylation was performed using the Hakomori method (Hakomori 1964). The methylated polysaccharides were then isolated by extraction with methylene chloride, dried down, and subjected to sequential hydrolysis $\left(2 \mathrm{M} \mathrm{TFA}, 120^{\circ} \mathrm{C}\right.$ for $2 \mathrm{~h}$ ), reduction (sodium borodeuteride, $\mathrm{NaBD}_{4}$ ), and acetylation using acetic anhydride and pyridine. The resulting partially methylated alditol acetates were analyzed by GC-MS using a $30 \mathrm{~m}$ Sp2330 column in a Hewlett-Packard 5985 GC-MS system using myo-inositol as internal standard. The following temperature conditions were used: $2 \mathrm{~min}$ at an initial temperature of $80^{\circ} \mathrm{C}$, increased to $170^{\circ} \mathrm{C}$ at $30^{\circ} \mathrm{C} / \mathrm{min}$, then to $240^{\circ} \mathrm{C}$ at $40{ }^{\circ} \mathrm{C} / \mathrm{min}$ and held 5 min at $240^{\circ} \mathrm{C}$.

\section{Results and Discussion}

The fractionation of leaf cell walls of $D$. fuscescens by chemical extraction yielded hemicelluloses as the major fraction (table 1). Although $\mathrm{NaClO}_{2}$ also

Table 1. Yield of cell-wall extraction from Dialypetalanthus fuscescens and Bathysa meridionalis.

\begin{tabular}{lrccccc}
\hline \multirow{3}{*}{ Fraction } & \multicolumn{5}{c}{ \% cell-wall dry wt } \\
\cline { 2 - 7 } & Yield & Total sugar ${ }^{\mathrm{a}}$ & Uronic acids $^{\mathrm{b}}$ & Yield & Total sugar & Uronic acids $^{\mathrm{b}}$ \\
\cline { 2 - 7 } & 21.4 & $5.8(27.1)^{\mathrm{c}}$ & 3.9 & 35.9 & $6.0(16.7)^{\mathrm{c}}$ & 2.6 \\
\hline $\mathrm{NaClO}_{2}$ & 6.6 & $2.2(33.3)$ & 2.2 & 10.7 & $3.9(36.4)$ & 4.5 \\
Ammonium Oxalate & 23.6 & $18.5(78.3)$ & 6.7 & 21.6 & $17.2(79.6)$ & 5.6 \\
$4 \mathrm{M} \mathrm{KOH}$ & 51.6 & 26.5 & 12.8 & 68.2 & 27.1 & 12.7 \\
\hline Total & 51.6 &
\end{tabular}

${ }^{a}$ Values are the yield of the fractions measured by the phenol-sulfuric method (Dubois et al. 1956) and ${ }^{\mathrm{b}}$ by the m-hydroxybiphenyl assay (Filisetti-Cozzi \& Carpita 1991); ${ }^{\mathrm{C}}$ The numbers in parenthesis represent the percentage of sugar in relation to the fraction yield. 
Table 2. Glycosyl composition of the polysaccharides of $\mathrm{NaClO}_{2}$, ammonium oxalate and $\mathrm{KOH}$ extracts from leaf cell walls of Dialypetalanthus fuscescens(Df) and Bathysa meridionalis(Bm).

\begin{tabular}{|c|c|c|c|c|c|c|c|c|c|c|}
\hline \multirow[t]{2}{*}{ Fraction } & \multirow[b]{2}{*}{ Species } & \multicolumn{9}{|c|}{ Component ${ }^{\mathrm{a}}(\mathrm{mol} \%)$} \\
\hline & & Rha & Ara & GalA & GlcA & Fuc & Xyl & Gal & Man & Glc \\
\hline \multicolumn{11}{|l|}{$\mathrm{NaClO}_{2}$} \\
\hline & $D f$ & 5.9 & 26.7 & 23.0 & 2.9 & 1.9 & 10.4 & 20.1 & 2.4 & 6.7 \\
\hline & $B m$ & 2.1 & 42.8 & 12.2 & - & 2.7 & 2.2 & 27.1 & 3.7 & 7.2 \\
\hline \multicolumn{11}{|c|}{ Ammonium Oxalate } \\
\hline & $D f$ & 7.1 & 22.8 & 32.1 & 3.8 & 1.6 & 11.5 & 15.9 & 1.0 & 2.7 \\
\hline & $B m$ & 8.4 & 22.2 & 32.8 & 4.8 & 1.4 & 6.3 & 15.6 & 1.7 & 5.2 \\
\hline \multicolumn{11}{|l|}{$4 \mathrm{M} \mathrm{KOH}$} \\
\hline & $D f$ & 6.4 & 19.4 & 19.3 & 3.4 & 1.2 & 25.1 & 12.8 & tr & 12.2 \\
\hline & $B m$ & 3.9 & 13.9 & 3.0 & 7.8 & - & 35.9 & 11.9 & 5.3 & 12.3 \\
\hline
\end{tabular}

${ }^{\text {a }}$ Apiose, 2-methyl Fucose and 2-methyl-Xylose were detected in trace amounts only in the ammonium oxalate fraction of both species. $-=$ not detected; $\operatorname{tr}=$ trace

Table 3. Glycosyl linkage composition analysis of neutral sugars from cell-wall fractions of Dialipetalanthus fuscescens (Df) and Bathysa meridionalis $(\mathrm{Bm})$.

\begin{tabular}{|c|c|c|c|c|c|c|}
\hline \multirow{2}{*}{ Deduced Linkage ${ }^{a}$} & \multicolumn{2}{|c|}{$\mathrm{NaClO}_{2}$} & \multicolumn{2}{|c|}{ Ammonium Oxalate } & \multicolumn{2}{|c|}{$4 \mathrm{M} \mathrm{KOH}$} \\
\hline & $D f$ & $B m$ & $D f$ & $B m$ & $D f$ & $B m$ \\
\hline$t$-Ara & 18.7 & 22.2 & 16.7 & 18.0 & 9.0 & 22.2 \\
\hline 2-Ara & 21.0 & 23.2 & 19.6 & 23.4 & 7.9 & 7.1 \\
\hline 3-Ara & 10.8 & 9.2 & 11.6 & 8.9 & 4.7 & 2.9 \\
\hline 4-Ara/ 5-Ara ${ }^{\mathrm{b}}$ & 6.9 & 6.0 & 3.4 & 3.3 & 2.4 & 1.1 \\
\hline$t$-Xyl & - & - & 1.7 & 1.7 & 5.9 & 4.0 \\
\hline 4-Xyl & 6.9 & 5.3 & 12.5 & 9.5 & 35.0 & 35.0 \\
\hline 2,4-Xyl & 2.0 & - & 1.6 & 1.7 & 3.3 & 4.3 \\
\hline 3-Man & - & - & 2.0 & 2.9 & 1.3 & 1.3 \\
\hline 4-Man & 3.8 & 4.7 & 3.7 & 3.6 & 3.1 & 2.7 \\
\hline 4,6-Man & - & - & - & - & 1.7 & 2.5 \\
\hline$t$-Gal & 3.6 & 8.4 & 5.9 & 4.8 & 3.0 & 5.2 \\
\hline 4-Gal & 6.6 & 5.5 & 4.7 & 3.8 & 2.3 & 1.7 \\
\hline 6-Gal & 2.2 & 4.8 & 2.3 & 2.3 & - & - \\
\hline 4,6-Gal & - & - & 1.4 & 2.0 & 6.5 & 8.7 \\
\hline $3,6-\mathrm{Gal}$ & 4.4 & 4.3 & 3.8 & 3.0 & - & - \\
\hline 2,4-Gal & - & - & - & - & 2.3 & - \\
\hline 3,4,6-Gal & - & - & 2.4 & - & - & - \\
\hline 4-Glc & 10.7 & 6.4 & 8.0 & 11.1 & 11.6 & 16.3 \\
\hline
\end{tabular}

a 2 -Rha and 2,4-Rha were detected only in trace amounts, ${ }^{\mathrm{b}}$ not distinguishable by the procedure, $-=$ not detected

extracted a significant amount of material, colorimetric analysis indicated that the carbohydrate content of this fraction was $27.1 \%$, compared with $78.3 \%$ for the $4 \mathrm{M} \mathrm{KOH}$ extract.

Differences in the amounts of material released from the walls by each extraction were found between $D$. fuscescens and B. meridionalis (table 1). Nevertheless, the total percentage of sugars and uronic acids recovered were similar for both species, accounting for ca. $27 \%$ and $13 \%$ of the cell wall dry wt, respectively. The carbohydrate content of the ammonium oxalate $(36.4 \%)$ and $\mathrm{KOH}(79.6 \%)$ extracts of $B$. meridionalis was also similar to those of $D$. fuscescens.

A delignification procedure also extracted part of the pectins from cell walls of $D$. fuscescens since the same sugar residues predominated in the $\mathrm{NaClO}_{2}$ and ammonium oxalate soluble fractions (table 2). The large amounts of arabinosyl and galactosyl residues found in these fractions, and the presence of 4-linked galactosyl residues and a high proportion of $t$-arabinosyl residues detected by glycosyl linkage 


\section{F. Moraes et al.: Polysaccharides of Dialypetalanthus fuscescens and Bathysa meridionalis}

composition analysis indicated the presence of arabinogalactans as the predominant neutral component of the pectic polysaccharides (table 3 ). Linkage analyses of these neutral components also revealed small amounts of 3,6-linked galactosyl residues suggesting that pectins from both fractions also contain type-II arabinogalactans (table 3 ). Arabinose and galactose were also the major neutral components found in $\mathrm{NaClO}_{2}$ and ammonium oxalate fractions of $B$. meridionalis (table 2). These sugars have been reported to constitute large proportion of the pectins from cell walls of Alibertia myrcifolia, another Cinchonoideae-Rubiaceae species from tropical forests (Braga et al. 1998).

Galacturonic acid was also found in high proportion in the $\mathrm{NaClO}_{2}$ and ammonium oxalate soluble fractions of $D$. fuscescens (table 2). 2- and 2,4-linked rhamnosyl residues commonly associated with rhamnogalacturoran-I were detected only in small amounts in these fractions (not shown). Although these findings suggest that homogalacturonans are the major acidic polysaccharides in the pectins of $D$. fuscescens, the possibility that considerable amounts of rhamnose were lost after derivatization can not be discarded.

The monosaccharide composition of ammonium oxalate soluble fraction from $B$. meridionalis was very similar to that of $D$. fuscescens (table 2). The rare sugars, 2-O-methyl fucose, 2-O-methyl xylose and apiose, typical of the rhamnogalacturoran-II portion of pectins, were detected in trace amounts in the ammonium oxalate fractions of both species.

The material extracted by strong alkali from the leaf cell walls of $D$. fuscescens and B. meridionalis
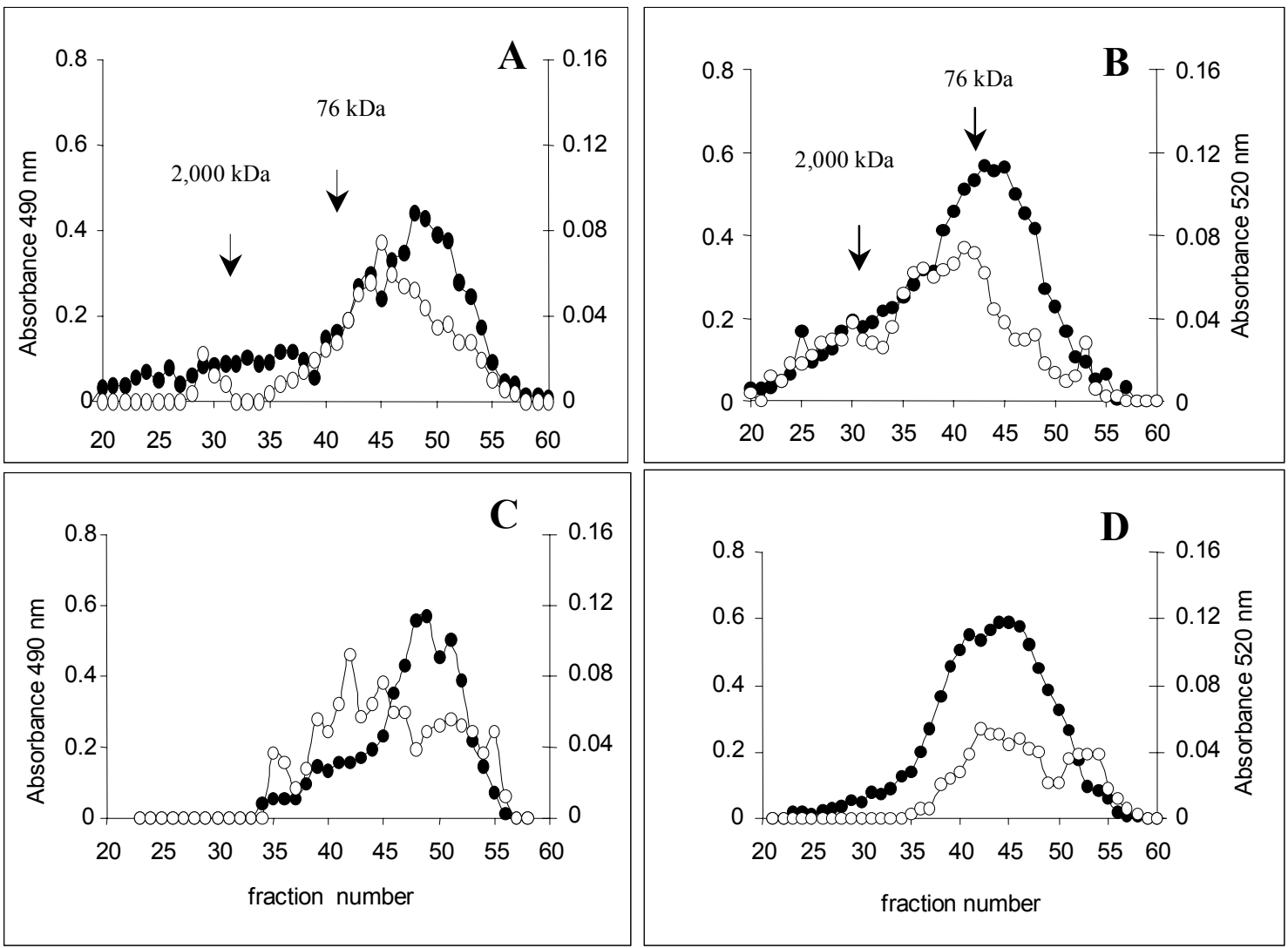

Figure 1. Sepharose 4B gel-permeation chromatography of $\mathrm{NaClO}_{2}(\mathrm{~A}, \mathrm{~B})$ and $4 \mathrm{M} \mathrm{KOH}(\mathrm{C}, \mathrm{D})$ extracts of cell walls from Dialypetalanthus fuscescens (A, C) and Bathysa meridionalis (B, D). Fractions (3 ml) were assayed colorimetrically for sugar content $(\bullet, \lambda 490 \mathrm{~nm})$ by the phenol-sulfuric method and for uronic acids $(\mathrm{o}, \lambda 520 \mathrm{~nm})$ by the m-hidroxybiphenyl procedure. 
was rich in xylose and contained considerable amounts of arabinose, galactose and glucose (table 2). From methylation analysis, 4-linked xylosyl was the most abundant linkage, indicating the presence of a xylan as the major fraction of the $\mathrm{KOH}$ extract of these species. This polymer appears to be branched at every 8-10 residues solely at the $\mathrm{O}-2$ position, as indicated by the relative amount of 2,4-linked xylosyl residues (table 3 ). The presence of this substituted xylan accounted in part for the $t$-Ara present in this fraction. Xylans, although being reported as a minor component of hemicelluloses from dicots and nongramineous monocots (Carpita \& Gibeaut 1993), were shown to predominate in leaf cell walls of two Cinchonoideae-Rubiaceae species from tropical environment (Braga et al. 1998). The linkage analyses (table 3 ) revealed a 4-linked xylan with a low degree of branching exclusively at the O-2 position, which could be explained, at least in part, due to the presence of secondary cell walls commonly found in leaf tissues. On the other hand, glycosyl linkages expected from xyloglucan of type-I walls (2-xylosyl, 4,6-glucosyl, 2-galactosyl and $t$-fucosyl) were not detected in the $\mathrm{KOH}$ fractions suggesting that this polysaccharide is present only in minute amounts in the cell walls of both species. Cell suspension cultures of $R$. jasminoides, a tropical Cinchonoideae-Rubiaceae species, show that, although xyloglucan is also present in their primary cell walls, the arabinoxylan is the predominant hemicellulosic polysaccharide found in the cells of this species (C.O. Fernandes, M.S. Buckeridge and M.R. Braga, unpublished data). These findings suggest that xylans instead of xyloglucans can account for most of the leaf hemicelluloses found in the Cinchonoideae species analysed and also in $D$. fuscencens.

4-Linked mannosyl residues, although detected in low amounts in $4 \mathrm{M} \mathrm{KOH}$ extracts and in the pectic material from $D$. fuscencens and $B$. meridionalis, indicated the presence of a glucomannan (table 3).

Gel permeation profiles of $\mathrm{NaClO}_{2}$ and $\mathrm{KOH}$ soluble fractions are shown in figure 1 . For both species, uronic acids of the $\mathrm{NaClO}_{2}$ fractions coeluted with the largest bulk of neutral sugars. Most of the pectic polymers of the $\mathrm{NaClO}_{2}$ fractions eluted at $\mathrm{Mr}$ lower than $76 \mathrm{kDa}$ (figure 1A, C). Total carbohydrate profile of $D$. fuscescens showed small amounts of polysaccharides of high $\mathrm{Mr}$ which were not detected in extracts of $B$. meridionalis (figure $1 \mathrm{~A}, \mathrm{C})$. The $\mathrm{KOH}$ extracts of both species also had similar elution patterns of neutral sugars on Sepharose $4 \mathrm{~B}$, presenting a broad peak centered around $76 \mathrm{kDa}$ (figure $1 \mathrm{C}, \mathrm{D}$ ). Although again in minor proportion, higher $\mathrm{Mr}$ polysaccharides were found only in $D$. fuscescens. Due to the very small amount of material available, ammonium oxalate fractions were not analysed by gel permeation chromatography.

From these results, we conclude that the cellwall polysaccharides of $D$. fuscescens and $B$. meridionalis have similar glycosyl and glycosyllinkage compositions. The presence of a xylan as the predominant hemicellulosic polysaccharide of leaf cell walls of $D$. fuscescens resembles the composition already reported for leaf cell walls of two Rubiaceae-Cinchonoideae (Braga et al. 1998), thus corroborating the current suggestion of a link between Dialypetalanthaceae and Rubiaceae. Additional leaf cell wall glycosyl and glycosyllinkage composition data from other species in families of the Gentianales would be necessary to substantiate the usefulness of cell wall composition data as a taxonomic marker. At present, such data are not available.

Acknowledgments - We thank Dr. Nicholas C. Carpita (University of Purdue, USA) for technical suggestions, and Dr. Marcos S. Buckeridge for the critical review of the manuscript. We also thank Dr. Parastoo Azadi (CCRC/UGA, USA) for the glycosyl and glycosyl linkage composition analyses. Thanks are due to CNPq (Brazil) for the fellowship to F. Moraes and for the research fellow grant to M.R. Braga. This work was also supported in part by FAPESP (BIOTASP, 98/05124-8, Brazil) and by the Department of Energy-funded (DE-FG05-93ER-20097) Center for Plant and Microbial Complex Carbohydrates.

\section{References}

BRAGA, M.R. \& DIETRICH, S.M.C. 1999. Cell wall components as taxonomic markers of higher plants. Anais da Academia Brasileira de Ciências 71:175-179.

BRAGA, M.R., PESSONI, R.A. \& DIETRICH, S.M.C. 1998. Cell wall polysaccharide composition of leaves of tropical Rubiaceae differing in phytoalexin response. Revista Brasileira de Fisiologia Vegetal 10:71-78.

BUCKERIDGE, M.S., ROCHA, D.C., PANEGASSI, V.R. \& DIETRICH, S.M.C. 1995. Seed galactomannan as marker in taxonomy and evolution of the Leguminosae. Phytochemistry 38:871-875.

CARNACHAN, S.M. \& HARRIS, P.J. 2000. Polysaccharide compositions of primary cell walls of the palms Phoenix canariensis and Rhopalostylis sapida. Plant Physiology and Biochemistry 38:699-708. 


\section{F. Moraes et al.: Polysaccharides of Dialypetalanthus fuscescens and Bathysa meridionalis}

CARPITA, N.C. 1996. Structure and biogenesis of the plant cell walls of grasses. Annual Review of Plant Physiology 47:445-476.

CARPITA, N.C. \& GIBEAUT, D.M. 1993. Structural models of primary cell walls in flowering plants: consistency of molecular structure with physical properties of the walls during growth. The Plant Journal 3:1-30.

CRONQUIST, A. 1968. The evolution and classification of flowering plants. Mifflin Houghton, Boston.

DAHLGREN, R. \& THORNE, R.F. 1984. The order Myrtales: circumscription, variation and relationships. Annals of the Missouri Botanical Garden 71:633-699.

DUBOIS, M., GILLES, A., HAMILTON, J.K., REBERS, P.A. \& SMITH, F. 1956. Colorimetric method for determination of sugars and related substances. Analytical Chemistry 28:350-355.

FILISETTI-COZZI, T.M.C. \& CARPITA, N.C. 1991. Measurement of uronic acids without interference from neutral sugars. Analytical Biochemistry 197:157162.

FRY, S.C. 1988. The growing plant cell wall: chemical and metabolic analysis. Longman, New York.

GORSHKOVA, T.A., WYATT, S.E., SALNIKOV, V.V., GIBEAUT, D.M., IBRAGIMOV, M.R., LOZOVAYA, V.V., \& CARPITA, N.C. 1996. Cell-wall polysaccharides of developing flax plants. Plant Physiology 110:721729.
HAKOMORI, S. 1964. A rapid permethylation of glycolipid and polysaccharide catalyzed by methylsulfinyl carbanion in dimethyl sulfoxide. Journal of Biochemistry (Tokyo) 55:205-208.

PIESSCHAERT, F., ROBBRECHT, E. \& SMETS, E. 1995. The systematic position of Dialypetalanthus. Second International Rubiaceae Conference. Scripta Botanica Belgica 11:21.

PIESSCHAERT, F., ROBBRECHT, E. \& SMETS, E. 1997. Dialypetalanthus fuscescens Kuhlm. (Dialypetalanthaceae): The problematic taxonomic position of an Amazonian endemic. Annals of the Missouri Botanical Garden 84:201-223.

REID, J.S.G.\& MEYER, H. 1970. Chemotaxonomic aspects of reserve galactomanans in leguminous seeds. Zeitschrift für Pflanzenphysiologie 62:89-92.

RIZZINI, C.T. \& OCCHIONI, P. 1949. Dialypetalanthaceae. Lilloa 17:243-288.

SZWEYKOWSKI, J. \& BUCZKOWSKA, K. 1999. Cell walls as taxonomic markers in Polish species of the genus Odontoschisma (Dum.) Dum. (Hepaticae, Cephaloziaceae). Acta Societatis Botanicorum Polonieae 61:39-45.

YORK, W.S., DARVILL, A.G., MCNEIL, M., STEVENSON, T.T. \& ALBERSHEIM, P. 1985. Isolation and characterization of plant cell walls and cell wall components. Methods in Enzymology 118:3-40. 